\title{
Penggunaan Biosorben Biji Pepaya Untuk Merekondisi Kualitas Minyak Jelantah
}

\author{
The Using Of Biosorbent Pepaya Seed To Recondition Of Fried Oil Quality \\ Muhammad Iqbal Nusa*, Yunan Bakri Sipahutar \\ Program Studi Teknologi Hasil Pertanian \\ Fakultas Pertanian Universitas Muhammadiyah Sumatera Utara \\ *Email: mhd.iqbal@umsu.ac.id
}

\begin{abstract}
ABSTRAK
Penelitian ini bertujuan melihat efektifitas biosorben biji papaya untuk mengembalikan mutu minyak jelantah. Pemahaman mekanisme adsorpsi, dan faktor yang berpengaruh pada kinerja adsorben perlu dipelajari. Total luas permukaan partikel dan lama waktu kontak adsorben dengan adsorbat menentukan kinerja adsorben. Pelaksanaan penelitian antara lain; pembuatan dan aktivasi biosorben biji Pepaya, dan pengujian efektifitas biosorben menggunakan Rancangan Acak Lengkap Faktorial dua faktor yaitu faktor rasio massa biosorben terhadap volume minyak goreng bekas (A) beberapa level; $A_{1}=5 \%, A_{2}=10 \%, A_{3}=15 \%$, dan $A_{4}=20 \%(b / v)$, dan faktor waktu kontak biosorben dengan minyak goreng bekas (L), beberapa level $\mathrm{L}_{1}=2, \mathrm{~L}_{2}=4, \mathrm{~L}_{3}=6$, dan $\mathrm{L}_{4}=8$ hari. Analisis data dapat dilihat pengaruh faktor perlakuan prosentase rasio massa biosorben terhdap volume minyak goreng bekas pada setiap level perlakuan $\mathrm{A}_{1} \mathrm{~A}_{2} \mathrm{~A}_{3}$ dan $\mathrm{A}_{4}$, menunjukkan pengaruh berbeda nyata $(\mathrm{p}<0.05)$, dan rerata nilai parameter; Bilangan Peroksida, Bilangan Asam, dan Kadar Air minyak goreng bekas cendrung menurun. Rerata nilai oganoleptik warna minyak goreng bekas meningkat dan menunjukkan pengaruh berbeda nyata antara perlakuan $A_{1}$ dengan $A_{2}, A_{3}$, dan $A_{4}$. Waktu kontak biosorben biji Pepayah dengan minyak goreng bekas, yaitu perlakuan $\mathrm{L}_{1}, \mathrm{~L}_{2}$, $\mathrm{L}_{3}$, dan $\mathrm{L}_{4}$, menunjukkan pengaruh berbeda nyata terhadap rerata nilai parameter Bilangan Peroksida, Bilangan Asam, dan Kadar Air minyak goreng bekas. Secara angka-angka rerata nilai parameter cedrung menurun. Sedangkan terhadap parameter nilai oganoleptik warna minyak goreng bekas, pengaruh faktor perlakuan $\mathrm{L}_{1}$ menunjukkan pengaruh berbeda nyata dengan perlakuan $\mathrm{L}_{2}$, $\mathrm{L}_{3}$, dan $\mathrm{L}_{4}$, dan nilai rerata cendrung meningkat.
\end{abstract}

Kata Kunci: Biji Pepaya, Biosorben, Minyak Jelantah, Rekondisi

\begin{abstract}
This research objective has to show the effectivity of the using biosorbent Papaya seed to recondition of fried oil quality. The adsorption mechanizme and the factors effected to performance of biosorbent must studied Comprehensively. Totality of extent particle surface and the long time of biosorbent with adsorbed interface determined performance adsorption. The research was compiled to producing and activating Papaya seed as biosorbent; and then to do the experiment for effectivity biosorbent according with Complete Random Factorial Design, with two factor namely Mass biosorbent to Volume fried oil ratio $\left(A_{1}=5 \%, A_{2}=10 \%, A_{3}=15 \%\right.$, dan $A_{4}=20 \%(b / v)$, and the long time of biosorbent fried oil interface $\left(\mathrm{L}_{1}=2, \mathrm{~L}_{2}=4, \mathrm{~L}_{3}=6\right.$, dan $\mathrm{L}_{4}=8$ days). The result of data analysis to show that effect of Mass biosorbent to Volume fried oil ratio factor have significant different among factor level properly $(\mathrm{p}<0.05)$, the mean value of Peroxide Number, Free Acid Number, and Water Content of fried oil were tendence to below. But the value of organoleptic colour was increase. Effect of the long time of biosorbent fried oil interface have significant different among factor level
\end{abstract}


properly $(\mathrm{p}<0.05)$, the mean value of Peroxide Number, Free Acid Number, and Water Content of fried oil were tendence to increase, and the value of organoleptic colour were also.

Keywords: Biosorbent, Fried oil, Papaya seed, Recondition

\section{A. PENDAHULUAN}

Perubahan sifat fisik dan kimia minyak goreng terjadi setelah penggunaan berkali-kali dengan suhu yang cukup tinggi (Belitz dan Grosch, 1999). Minyak menjadi cepat berasap, berbusa, dan meningkatkan warna coklat serta flavor yang tidak enak (Ketaren, 2008; Wijaya, 2005). Karakteristik minyak goreng ditentukan oleh kadar air, bilangan asam, bilangan peroksida dan kerapatan jenis bahan. Peningkatkan asam lemak bebas yang terbentuk dari hasil reaksi hidrolisis akibat dari keberadaan air dalam minyak, penguraian bentuk trigliserida menjadi asam lemak bebas, dan pemanasan minyak pada suhu yang tinggi. Sehingga menyebabkan terbentuknya senyawa hasil oksidasi lemak dan minyak yang membentuk gugus fungsional aldehid dan keton sebagai indikasi terjadi ketengikan (rancidity) pada minyak goreng (Ketaren, 2008; Istighfaro, 2010; Atsushi dan Mitshutoshi, 2003).

Minyak goreng berfungsi sebagai penghantar pengantar panas, penambah rasa gurih, dan penambah nilai gizi/ kalori bahan pangan, (Winarno 1992 dalam Setyawan, dkk. 2009).Penggunaan minyak bekas penggorengan (minyak jelantah) apabila makanan tersebut dikonsumsi akan mengganggu kesehatan seperti penyakit kanker, penumpukan Trans Fatty Acid (TFA) di dalam pembuluh darah, penurunan nilai cerna lemak dan minyak sehingga menurunkan kecerdasan generasi berikutnya (Lusiana dan Sutantu, 2005; Nur, 2008 dalam Girsang dkk. 2015). Radikal peroksi yang ada dalam minyak dapat menimbulkan kerusakan DNA (Sykes, 1995). Sedangkan hidrolisis gliserol menghasilkan akrolein yang menimbulkan rasa gatal ditenggorokan, (Winarno 1992 dalam Setyawan, dkk. 2009).

Adsorben dari biomaterial atau Biosorben dapat digunakan untuk mengembalikan mutu minyak jelantah. Biosorben dihasilkan dari bahan yang mengandung karbon berfungsi sebagai purifikasi atau pemisah komponen pada fase gas atau cairan, merupakan zat padat yang digunakan untuk menjerap komponen tertentu suatu fase fluida atau Adsorbat (Fatin, 2015). Pemanfaatan Biosorben untuk menjerap gugus fungsi pada minyak untuk pemurnian minyak jelantah sangat potensial (Kaur et al, 2012). Peningkatan kualitas minyak jelantah dengan karbon aktif melalui proses adsorpsi yang menjerap zat warna, suspensi koloid hasil degradasi minyak, (Rosita, 2009). Bahan biomaterial yang sudah digunakan antara lain buah Mengkudu, ampas Nanas, biji Kelor (Katayon et al, 2006). Arang kayu, arang sekam, dan ampas tebu (Wijayanti, 2009), tempurung biji jambu mede (Rasjidin, 2006), dan arang biji salak (munaf et al, 2014; Kurniadin dan Murdiono, 2011).

Kinerja biji papaya sebagai bahan Biosorben sudah diujikan untuk penyerapan zat warna. Biosorben biji papaya dengan ukuran partikel 60 mesh dengan aktivasi dengan senyawa asam sulfat $98 \%$ untuk penyerapan methyl blue menghasilkan kapasitas adsorpsi dengan metode Langmuir adalah 55,557 mg/g, (Hameed, 2009). Biosorben biji papaya untuk penyerapan Kristal violet diperoleh luas permukaan adsorpsi 27,5 m²/g, (Yadrav, et al. 2014). Peningkatan luas permukaan biosorben dengan perlakuan awal berfungsi sebagai aktivasi biosorben biji papaya, menggunakan beberapa konsentrasi Asam Sulfat dan lama pemanasan terhadap kapasitas adsorpsi yang dinyatakan sebagai bilangan iodin (mg/g). Jumlah iodin yang dapat dijerap per satuan berat biosorben menunjukkan bilangan iodin yang tertinggi $782,220 \mathrm{mg} / \mathrm{g}$, diperoleh dari aktivasi bubuk biji papaya pada konsentrasi Asam Sulfat $10 \%$ dan lama pemanasan 120 menit (Siswarni, et al, 2015). Luas permukaan Biosorben yang sudah memenuhi standar kualitas biosorben menurut SNI 06-3730-1995 adalah kemampuan adsopsi biosorben lebih tinggi atau sama dengan $760 \mathrm{mg} / \mathrm{g}$ (Herlin et al, 2013).

Tujuan penelitian ini adalah melihat bagaimana efektifitas penggunaan biosorben dari bahan biji pepaya dalam mengembalikan mutu minyak jelantah. Sehingga diperlukan pemahaman yang berkaitan dengan proses adsorpsi, dan faktor yang mempengaruhi kinerja adsorben. Intensitas kontak antara permukaan adsorben dengan adsorbat, 
ditentukan oleh luar permukaan partikel adsorben, massa adsorben yang digunakan, dan waktu kontak adsorben dengan adsorbat.

\section{B. METODOLOGI \\ Bahan dan Alat}

Bahan yang digunakan adalah minyak goreng bekas lima kali penggorengan, biji pepaya, $\mathrm{H}_{2} \mathrm{SO}_{4} 98 \%$, indikator $\mathrm{PP}$, aquadest, etanol 96\%, $\mathrm{NaOH}$, KI hablur.

Alat yang digunakan adalah oven, blender, erlenmeyer, neraca analitik, kertas saring, ayakan, pengaduk, termometer, pipet tetes, desikator, beaker glass. Erlenmeyer.

\section{Rancangan Penelitian}

Rancangan penelitian yang digunakan adalah Acak Lengkap Faktorial, dengan dua faktor perlakuan dan dua ulangan. Analisa data menggunakan Analisa Varian (ANOVA) untuk melihat pengaruh faktor perlakuan, dan dilanjutkan uji beda rerata terkecil (BNT) untuk memperlihat perbedaan antar level perlakuan, pada taraf nyata $(\mathrm{P}<0,05)$ atau sangat nyata $(\mathrm{P}<0,01)$.

\section{Pelaksanaan Penelitian \\ Pembuatan dan Aktivasi Biosorben biji Pepaya}

Pengumpulan dan sortasi. Biji pepaya yang dipisahkan dari buahnya lalu di cuci bersih. Biji Pepaya dikering ovenkan pada suhu sedang $65^{\circ} \mathrm{C}$ selama 7 jam, kemudian biji pepaya di haluskan menggunakan blender, dilakukan penyeragaman ukuran menggunakan ayakan berukuran 60 mesh, sehingga diperoleh tepung biji pepaya sebagai Biosorben. Kemudian Biosorben biji Pepaya diaktivikasi secara kimia dengan asam sulfat konsentrasi $10 \%$ dan dicuci dengan aqaudest lalu dikeringkan dengan oven selama 12 jam pada suhu $105^{\circ} \mathrm{C}$, (Siswarni et al, 2015).

\section{Pengujian Biosorben biji Pepaya untuk merekondisi Mutu Minyak goreng bekas}

Penyiapan sampel minyak goreng bekas 5 kali penggorengan dipakai sebagai bahan uji sebanyak masing-masing $100 \mathrm{ml}$. kemudian sampel bahan uji diperlakukan dengan Biosorben biji Pepaya yang disesuaikan dengan faktor perlakuan I (A) yaitu angka rasio dari jumlah biosorben terhadap volume minyak goreng bekas pada beberapa level yaitu; $\mathrm{A}_{1}=5$ $\%, \mathrm{~A}_{2}=10 \%, \mathrm{~A}_{3}=15 \%$, dan $\mathrm{A}_{4}=20 \%(\mathrm{~b} / \mathrm{v})$.
Efektifitas kinerja Biosorben diukur melalui pengamatan terhadap beberapa parameter mutu minyak goreng bekas setelah melewati waktu kontak biosorben biji Pepaya dengan minyak goreng bekas (L), pada beberapa lama sebagai faktor perlakuan II yaitu; $\mathrm{L}_{1}=2, \mathrm{~L}_{2}=4$, $\mathrm{L}_{3}=6$, dan $\mathrm{L}_{4}=8$ hari.

\section{Pengamatan \\ Parameter-parameter yang diamati menunjukkan perubahan terhadap mutu minyak goreng antara lain;}

\section{Bilangan Peroksida}

Bilangan atau angka peroksida menunjukkan indeks jumlah lemak atau minyak yang telah mengalami oksidasi. Bilangan peroksida ditentukan menggunakan metode titrasi iodometri. Bilangan IOD adalah jumlah gram iod yang dapat diikat oleh 100 gram minyak. Ikatan rangkap pada minyak akibat oksidasi minyak akan bereaksi dengan senyawa iod. Titik akhir titrasi dinyatakan oleh hilangnya warna biru dengan indicator amilum, menggunakan formula sebagai berikut

Bil. Peroksida (\%) $=\frac{(V b-V p) x B s t x 100}{\text { BeratSampel }}$

\section{Bilangan Asam}

Bilangan asam adalah jumlah milligram $\mathrm{KOH}$ yang dibutuhkan untuk menetralkan asamasam lemak bebas di dalam satu gram minyak atau lemak. Bilangan asam digunakan untuk mengukur jumlah asam lemak bebas dalam minyak, dengan cara melarutkan minyak dalam alcohol-ether dan penambahan indikator phenophthalen. Kemudian dilakukan titrasi dengan larutan $\mathrm{KOH} \mathrm{0,5} \mathrm{N} \mathrm{sampai} \mathrm{terbentuk}$ perubahan warna merah jambu yang tetap, maka bilangan asam dihitung dengan formula berikut.

Bilangan Asam (\%) =

$$
\frac{\text { mlKOHxNKOHxBMAsamLemakx100 }}{\text { BeratContoh },(\text { gram })}
$$

\section{Kadar Air Minyak}

Menentukan angka kadar air minyak dilakukan dengan metode thermogravimetri, yaitu sampel minyak sebanyak 10 gram dimasukkan ke dalam botol timbang dengan mulut lebar. Kemudian di oven pada suhu $105^{\circ} \mathrm{C}$ sampai dicapai berat konstannya. Selisih berat menunjukkan berat air dalam minyak 
yang menguap yang dihitung dengan formula berikut

Kadar air Minyak $(\%)=\frac{A-B \times 100}{A}$

Dimana; A berat sampel wal sebelum dioven (gram), B berat konstan setelah dioven, (gram).

\section{Organoleptik Warna}

Uji organoleptik Warna ditentukan melalui panelis, pengujian terhadap warna minyak sampel diberikan penilaian oleh panelis berdsarkan pada skala hedonik dan skala numerik (Soekarto, 1982).

Tabel 1 Skala hedonik dan numerik uji organoleptik warna Minyak Goreng bekas

\begin{tabular}{clc}
\hline No. & \multicolumn{1}{c}{ Skala Hedonik } & Skala Numerik \\
\hline 1 & Kuning pucat & 4 \\
2. & Kuning & 3 \\
3. & Kuning kecoklatan & 2 \\
4. & Coklat & 1 \\
\hline
\end{tabular}

\section{HASIL DAN PEMBAHASAN}

\section{Pengaruh Rasio Jumlah Biosorben Terhadap} Volume minyak

Dari hasil uji sidik ragam pengaruh interaksi faktor perlakuan rasio jumlah biosorben biji pepaya dengan volume minyak goreng bekas, dengan faktor lama waktu kontak biosorben dengan minyak goreng terhadap parameter mutu minyak goreng bekas tidak menunjukkan perbedaan nyata. Sehingga analisis hasil yang dilakukan hanya untuk melihat pengaruh dari masing-masing faktor perlakuan seperti pada Tabel 2 berikut.

Tabel 2 Pengaruh rasio jumlah Biosorben Biji Pepaya dengan volume minyak goreng bekas Terhadap Parameter mutu minyak goreng.

\begin{tabular}{|c|c|c|c|c|}
\hline \multirow{2}{*}{$\begin{array}{l}\text { Faktor Perlakuan } \\
\text { Jumlah } \\
\text { Biosorben Biji } \\
\text { Pepaya } \\
\text { Terhadap } \\
\text { Volume Minyak } \\
\text { Goreng bekas, } \\
\text { (A) }\end{array}$} & \multicolumn{4}{|c|}{ Nilai rerata Parameter } \\
\hline & $\begin{array}{l}\text { Bil. } \\
\text { Peroksida } \\
(\%)\end{array}$ & $\begin{array}{l}\text { Bil. } \\
\text { Asam } \\
(\%)\end{array}$ & $\begin{array}{c}\text { Kadar } \\
\text { Air } \\
\text { Minyak } \\
(\%)\end{array}$ & $\begin{array}{c}\text { Organo } \\
\text {-leptik } \\
\text { Warna } \\
\text { Minyak }\end{array}$ \\
\hline$A_{1}=5 \%$ & $0,213 \mathrm{a}$ & $1,715 \mathrm{a}$ & $0,167 \mathrm{a}$ & $3,18 \mathrm{a}$ \\
\hline$A_{2}=10 \%$ & $0,152 \mathrm{~b}$ & $1,496 \mathrm{~b}$ & $0,142 \mathrm{~b}$ & $3,13 \mathrm{~b}$ \\
\hline$A_{3}=15 \%$ & $0,094 \mathrm{~b}$ & $1,320 \mathrm{c}$ & $0,126 \mathrm{c}$ & $3,08 \mathrm{~b}$ \\
\hline $\mathrm{A}_{4}=20 \%$ & $0,051 \mathrm{c}$ & $1,117 \mathrm{~d}$ & $0,108 \mathrm{~d}$ & $3,00 \mathrm{~b}$ \\
\hline
\end{tabular}

Keterangan: Huruf yang berbeda pada kolom notasi menunjukkan pengaruh berbeda nyata pada taraf $(P<0,05)$
Pada tabel 2 dapat dilihat bahwa, pengaruh faktor perlakuan rasio jumlah biosorben dengan volume minyak goreng bekas setiap level perlakuan (Faktor $\mathrm{A}_{1} \mathrm{~A}_{2} \mathrm{~A}_{3}$ dan $\mathrm{A}_{4}$ ), menunjukkan berbeda nyata terhadap nilai parameter Bilangan Peroksida, Bilangan Asam, dan Kadar Air minyak goreng bekas yang diperlakukan dengan biosorben biji papaya. Sedangkan terhadap parameter nilai oganoleptik warna minyak goreng bekas, pengaruh faktor perlakuan level $A_{1}$ menunjukkan perbedaan nyata dengan perlakuan level $A_{2}, A_{3}$, dan $A_{4}$.

Rerata nilai Bilangan Peroksida, Bilangan Asam, dan Kadar air minyak goreng menurun, dan rerata nilai organoleptik warna meningkat dengan bertambahnya jumlah biosorben biji papaya yang digunakan untuk setiap voleme minyak goreng bekas yang diperlakukan. Pengaruh angka rasio biosorben biji pepaya terhadap nilai rerata Bilangan peroksida, Bilangan Asam lemak bebas, Kadar air minyak goreng bekas dan nilai organoleptik warna secara angka-angka dijelaskan melalui grafik pada gambar 1, 2, 3, dan 4 berikut.

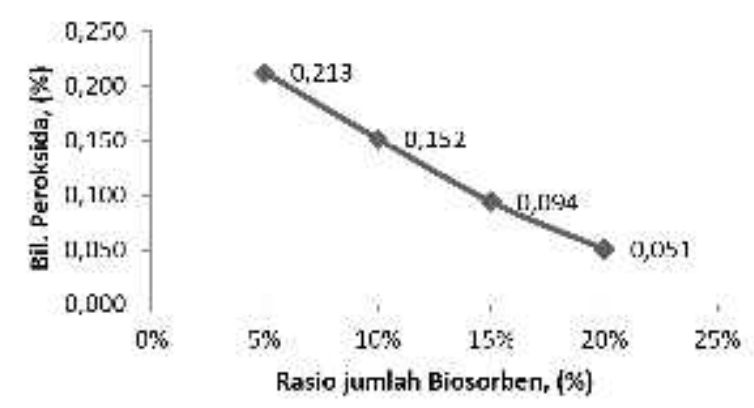

Gambar 1 Grafik pengaruh rasio jumlah relative biosorben dengan volume minyak terhadap Bilangan peroksida

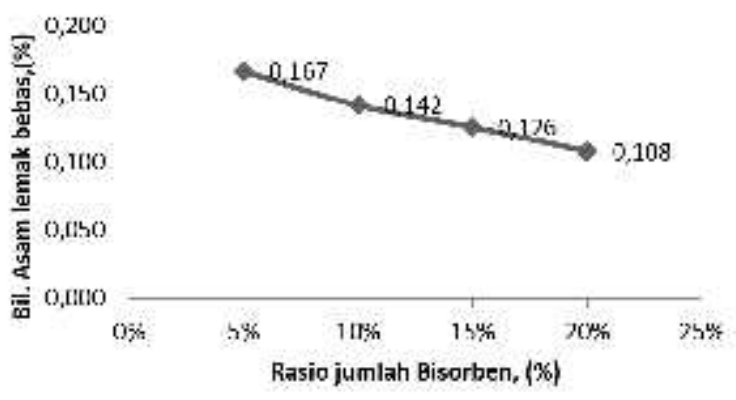

Gambar 2 Grafik pengaruh rasio jumlah relative biosorben dengan volume minyak terhadap Bilangan Asam lemak bebas 


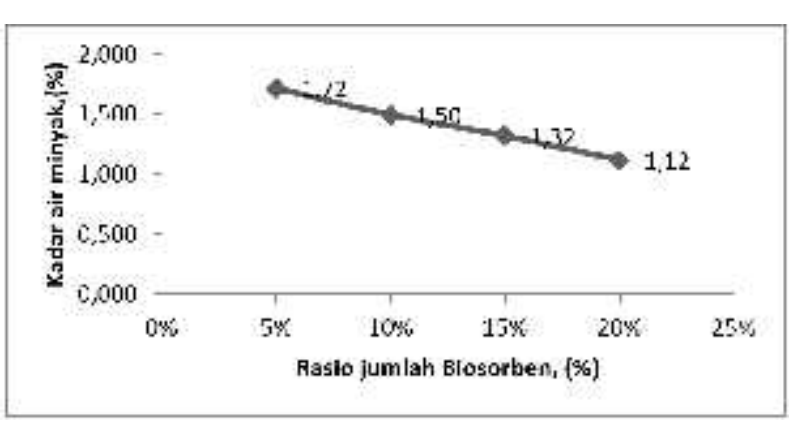

Gambar 3 Grafik pengaruh rasio jumlah relative biosorben dengan volume minyak terhadap Bilangan Asam lemak bebas

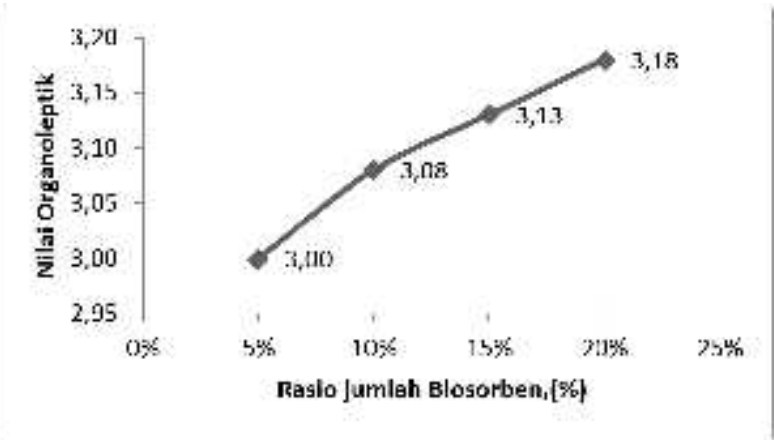

Gambar 4 Grafik pengaruh rasio jumlah relative biosorben dengan volume minyak terhadap nilai organoleptik warna minyak goreng

Rasio jumlah biosorben meningkat secara relative terhadap volume minyak goreng bekas, menyebabkan luas permukaan total biosorben sebagai permukaan interface akan bertambah luas. Jumlah partikel adsorben yang melakukan kontak dengan minyak goreng bekas semangkin banyak, sehingga aliran massa molekul adsorbat dari minyak goreng bekas ke dalam pori partikel biosorben biji papaya akan meningkat. Penurunan bilangan peroksida minyak goreng bekas menunjukkan bahwa biosorben biji papaya mengadsorpsi komponen adsorbat dalam minyak goreng bekas melalui ikatan hidrogen dari gugus silanol dengan gugus peroksida pada permukaan adsorben (Kinanthi, 2008).

Kinerja biosorben mengikuti mekanisme proses adsorpsi yang berlangsung yaitu, molekul-molekul adsorbat yang dijerap oleh patikel adsorben bergerak ke permukaan interface yaitu lapisan film yang melapisi permukaan biosorben. Molekul adsorbat terus bergerak sebagai aliran massa dari permukaan luar partikel ke dalam porositas partikel adsorben, akhirnya molekul adsorbat menempel pada permukaan pori adsorben, Suhendra dan Gunawan, 2010).

Karakteristik minyak goreng yang digunakan berulang-ulang yang dikenal sebagai minyak jelantah, sudah mengalami kerusakan yang indikatornya antara lain meningkatnya Bilangan Peroksida empat kali dari minyak goreng yang baru. Bilangan peroksida merupakan suatu nilai untuk menentukan derajad kerusakan minyak (Ketaren, 1986 dalam Setyawan et al, 2009), asam lemak semangkin aktif terhadap oksigen dengan bertambahnya ikatan rangkap (Swee, et al. 2006 dalam Setyawan, dkk.,2009). Kerusakan minyak jelantah ditandai dengan tingginya kandungan asam lemak bebas berkisar 3,144\%. Meningkatnya asam lemak bebas terbentuk dari reaksi hidrolisis dengan adanya air, temperature yang tinggi, dan proses oksidasi pada ikatan rangkap (Atsushi, et al. 2003). Minyak goreng yang berkualitas baik kandungan asam lemak bebas adalah sekitar 0,1\% (Ramdja, dkk., 2010). Penurunan bilangan asam minyak jelantah hingga kadar terendah hingga $0,629 \%$ dapat dicapai dengan mekanisme adsorpsi menggunakan biosorben serabut kelapa ukuran partikel 100 mesh dengan waktu kontak 90 menit, dan penurunan bilangan asam hingga 0,449\% menggunakan biosorben jerami (Pakpahan et al, 2014).

\section{Pengaruh Lama Waktu Kontak Biosorben Dengan Minyak}

Dari hasil pengamatan dan uji sidik ragam pengaruh perlakuan lama waktu kontak biosorben biji Pepaya dengan minyak goreng bekas terhadap parameter mutu minyak goreng dapat dilihat pada Tabel 3 berikut.

Tabel 3 Pengaruh Lama waktu kontak biosorben biji Pepaya dengan minyak goreng bekas Terhadap Parameter mutu minyak goreng.

Faktor perlakuan

Lama waktu Nilai rerata Parameter

kontak

biosorben biji Bil. Bil. Kadar Organo-

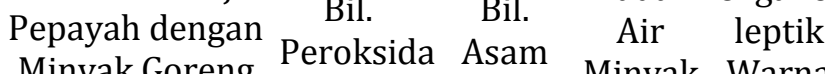

Minyak Goreng $\begin{gathered}\text { Peroksida Asam Minyak Warna } \\ \text { (\%) }\end{gathered}$

$\begin{array}{lllll}\text { bekas, (L) } & (\%) & (\%) & (\%) & \text { Minyak }\end{array}$

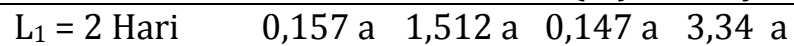

$\mathrm{L}_{2}=4$ Hari $\quad 0,131 \mathrm{~b} \quad 1,414 \mathrm{~b} \quad 0,137 \mathrm{~b} \quad 3,40 \mathrm{~b}$

$\mathrm{L}_{3}=6$ Hari $\quad 0,120 \mathrm{c} \quad 1,384 \mathrm{c} \quad 0,134 \mathrm{c} \quad 3,42 \mathrm{~b}$

$\mathrm{L}_{4}=8$ Hari $\quad 0,102 \mathrm{~d} \quad 1,339 \mathrm{~d} \quad 0,126 \mathrm{~d} \quad 3,45 \mathrm{~b}$

Keterangan: Huruf yang berbeda pada kolom notasi menunjukkan pengaruh berbeda nyata pada taraf $(P<0,05)$ 
Pada tabel 3 dapat dilihat bahwa, pengaruh faktor perlakuan lama waktu kontak biosorben biji Pepayah dengan minyak goreng bekas (L) antara setiap level perlakuan (Faktor $\mathrm{L}_{1}, \mathrm{~L}_{2}, \mathrm{~L}_{3}$, dan $\mathrm{L}_{4}$ ), menunjukkan berbeda nyata terhadap nilai parameter Bilangan Peroksida, Bilangan Asam, dan Kadar Air minyak goreng bekas. Sedangkan terhadap parameter nilai oganoleptik warna minyak goreng bekas, pengaruh factor perlakuan level $\mathrm{L}_{1}$ menunjukkan perbedaan nyata dengan perlakuan level $\mathrm{L}_{2}$, $\mathrm{L}_{3}$, dan $\mathrm{L}_{4}$.

Rerata nilai Bilangan Peroksida, Bilangan Asam, dan Kadar air minyak goreng menurun, dan rerata nilai organoleptik warna meningkat dengan bertambah lamanya waktu kontak biosorben biji Pepaya dengan minyak goreng bekas yang diperlakukan. Pengaruh lamanya waktu kontak biosorben biji pepaya terhadap nilai rerata Bilangan peroksida, Bilangan Asam lemak bebas, Kadar air minyak goreng bekas dan nilai organoleptik warna secara angkaangka dijelaskan melalui grafik pada gambar 5 , 6,7 , dan 8 berikut.

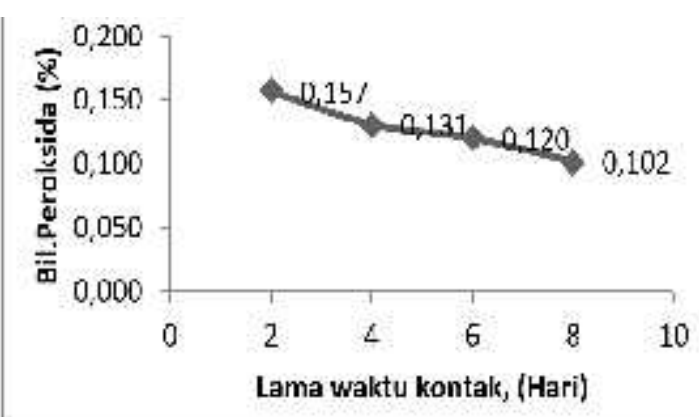

Gambar 5 Grafik pengaruh Lama waktu kontak biosorben dengan minyak goreng bekas terhadap Bilangan peroksida

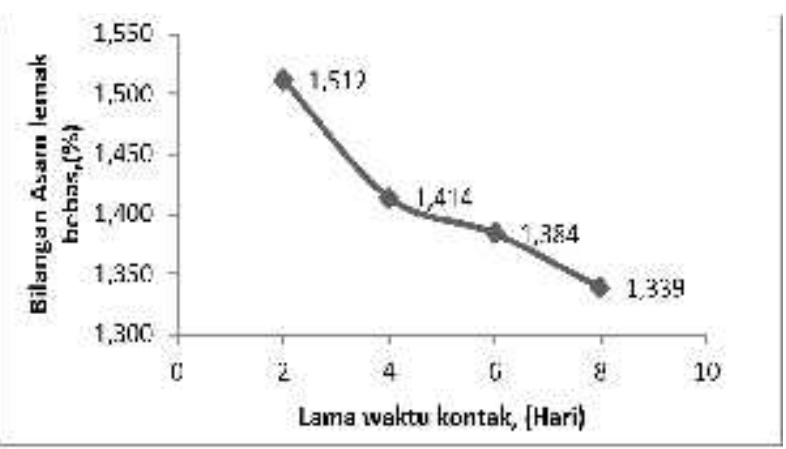

Gambar 6 Grafik pengaruh Lama waktu kontak biosorben dengan minyak goreng bekas terhadap Bilangan Asam Lemak Bebas

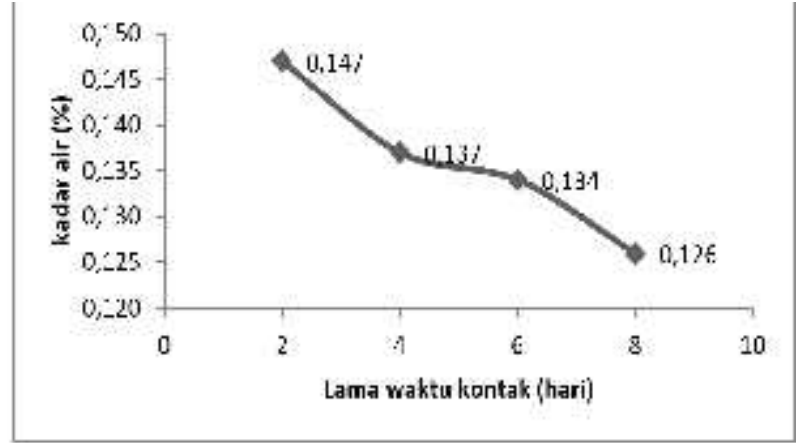

Gambar 7 Grafik pengaruh Lama waktu kontak biosorben dengan minyak goreng bekas terhadap Kadar Air minyak goreng

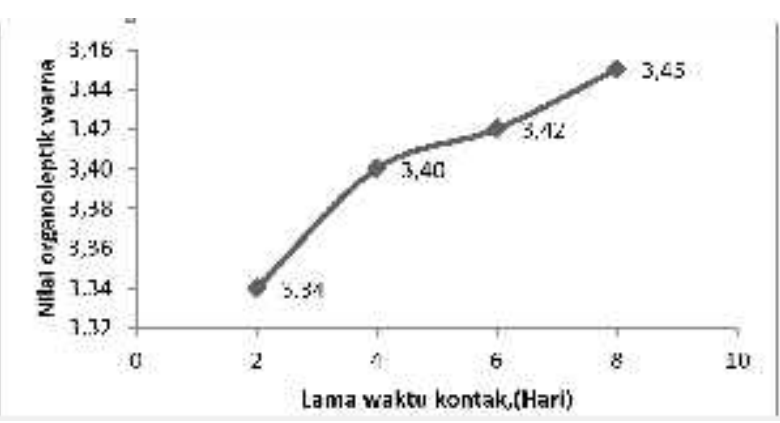

Gambar 8 Grafik pengaruh Lama waktu kontak biosorben dengan minyak goreng bekas terhadap Nilai Organoleptik minyak goreng

Penurunan rerata bilangan peroksida, bilangan asam lemak bebas, dan kadar air minyak goreng bekas sebagai pengaruh semangkin lama waktu kontak biosorben dengan minyak goreng. Semangkin lama waktu kontak biosorben dengan minyak jelantah, maka mekanisme adsorpsi akan berlangsung lebih lama pula dimana molekul-molekul adsorbat yang dijerap oleh patikel adsorben bergerak ke permukaan interface yaitu lapisan film yang melapisi permukaan biosorben. Molekul adsorbat terus bergerak sebagai aliran massa dari permukaan luar partikel ke dalam porositas partikel adsorben, akhirnya molekul adsorbat menempel pada permukaan pori adsorben, Suhendra dan Gunawan, 2010). Laju kemampuan adsorpsi biosorben biji papaya terhadap adsorbat minyak goreng bekas secara angka-angka menunjukkan penurunan sejalan dengan bertambah waktu kontak biosorben dengan minyak jelantah. Fenomena yang sama juga dapat dilihat pada penggunaan biosorben serabut kelapa dan jerami untuk pemurnian minyak goreng bekas (Pakpahan et al, 2014); 
dan penggunaan biosorben ampas tebu (Ramdja et al, 2010)

\section{KESIMPULAN}

Berdasarkan hasil penelitian yang dilakukan, dapat diambil simpulan sebagai berikut:

1. Rasio jumlah biosorben biji Pepaya terhadap Volume minyak goreng bekas yang diperlakukan, menunjukkan berpengaruh nyata terhadap kemampuan dalam menurunkan Bilangan Peroksida, Bilangan Asam Lemak Bebas, Kadar Air Minyak goreng bekas yang dihasilkan, dan peningkatan nilai organoleptik warna minyak goreng bekas.

2. Lama waktu kontak biosorben biji Pepaya dengan minyak goreng bekas menunjukkan berpengaruh nyata terhadap kemampuan dalam menurunkan Bilangan Peroksida, Bilangan Asam Lemak Bebas, Kadar Air Minyak goreng bekas yang dihasilkan, dan peningkatan nilai organoleptik warna minyak goreng bekas

\section{DAFTAR PUSTAKA}

Atsushi M; Rangaswamy; Mitsutoshi, N. 2003. Membrane And Additional Adsorption Processes for Quality improvement for Used Frying Oils. JAOCS. 80: 927-932

Badan Standar Nasional (BSN). 2002. SNI013741-2013. Minyak Goreng. Badan Standarisasi Nasional. Jakarta.

Belitz, H.D and W. Grosch. 1999. Food Chemistry. Second edition. SpringerVerlag. Berlin. Heidelberg.

Emi Girsang, A.Kiswandono, H. Azis, Z.Chaidir, R.Zein. 2015. Serbuk Biji Salak (Salacca Zalacca) Sebagai Biosorben Dalam Memperbaiki Kualitas Mnyak Goreng Bekas. Prosiding Seminar Nasional Pendidikan Sains.

Fatin, D.M. 2015. Modifikasi Adsorben Berbasis Katu Randu Dengan metode Pemanasan dan penerapan sebagai bahan penyerap Aktivator Asam Sulfat Penggunaan Sebagai Penjerap Ion Tembaga. Makara Sains. Vol 14, No.1

Hameed, B.H. 2009. Evaluation of Papaya Seed as Novel Non Conventional Law Cost
Adsorbent for Remove of Methylene Blue. Journal of Hazardous Material.

Istighfaro, Nila. 2010. Peningkatan Kualitas Minyak Goreng Bekas Dengan metode Adsorpsi Menggunakan Bentonit-Karbon Aktif Biji Kelor (Moringa Oleifera Lamk). [Skripsi]. Universitas Islam negeri Malik Ibrahim. Malang

Katayon, S., N.,M.J. Asma, M.Gani, A.M. Suleyman. 2006. Effects of Storage Conditions of Moringa Oleifera Seeds on its Performance in Coagulation. Bioresource Technology. 97: 1455-1460

Kaur, R.,J.Sing, R.Khare, A.Ali. 2012. Biosorption The Possible Alternative to Existing Conventional Technologies for Sequence Heavy Metal Ions from Aquaeous Stream. A Review. Universal Journal of Env. Res. And Technol. 2(4):325-335

Ketaren, S. 1986. Pengantar Teknologi Minyak dan Lemak Pangan. Penerbit Universitas Indonesia.

Kurniadin, A. dan Murdiono. 2011. Penjernihan Minyak Goreng Bekas Dengan Proses Adsorpsi Menggunakan Arang Biji Salak. [Skripsi]. Jurusan Teknik Kimia. Fakultas Teknik. Universitas Diponegoro. Semarang

Munaf, E., Fitra,H.,R. Suyani. 2014. The Use of Snake Fruit (Salacca Sumatrana) Seeds Powder for Removal of Cd (II), Cu (II), and Zn (II) Ions. Envirounmental Water Resourch. Journal of Pham. Bio and Chem. Sci 5(2): 535-539

Pakpahan, J.F; T. Tambunan; A Harimby; M.Y. Ritonga. 2014. Pengurangan Free Fatty Acid (FFA) dan Warna Minyak Jelantah Dengan Adsorben Serabut Kelapa dan Jerami. Program Studi Teknik Kimia Universitas Sumatera Utara.

Pavan, F.A; E.S. Campico; E. L. Guelherme, and V.T.A Branco. 2014. Formation Pepaya Seed Powder. Preparation Characterization and Application as on Alternative Adsorbent for Removal of Crystal Violet From Aqueous Phase. Journal 
of Envirounmental Chemical Engiineering Vol.2. 230-238

Ramdja, A.F; L Febrina; D. Krisdianto. 2010. Pemurnian Minyak Jelantah Menggunakan Ampas Tebu Sebagai Biosorben. Jurnal Teknik Kimia. Vol.17. No.1.

Rasjiddin, R. 2006. Pembuatan Arang Aktif Dari Tempurung Biji Jambu Mede (Anacardium Occidentale) Sebagai Adsorben Pada Permurnian Minyak Goreng Bekas. [Skripsi]. Departemen Teknologi Industri Pertanian. FTP. IPB. Bogor

Rosita, Alinda. 2009. Peningkatan Kualitas Minyak Goreng Bekas KFC Menggunakan Adsorben Arang Aktif. [Skripsi]. Jurusan Teknik Kimia. Universitas Diponegoro. Semarang.

Setyawan, D; P. Handoko; Tryono; Narsito; Tutik, D. 2009. Peningkatan Kualitas Minyak Jelantah Menggunakan Adsorben H5-NZA Dalam Reaktor Sistem Fluid Fixed Bed. Universitas Jember. Jurnal Ilmu Dasar. Vol. 10. No.2

Siswani, M.Z; L.I. Ranita; D. Safitri. 2015. Pembuatan Biosorben Dari Biji Pepaya (Carica Papaya L) Untuk Penyerapan zat Warna. Program Studi Teknik Kimia Universitas Sumatera Utara. Medan

Swee, Y.F; Susan, C; S. Vicki. 2006. Evaluation of SafTest Methode for Monitoring Frying Oil Quality. JAOCS.83. 15-20

Sykes, P. 1995. A Primer to Mechanism in Organic Chemestry. Edinburgh. Addison Longman Ltd.

Wijayanto, R. 2009. Arang Aktif Dari Ampas Tebu Sebagai Adsorben Pada pemurnian Minyak Goreng Bekas. [Skripsi]. Departemen Kimia. MIPA. IPB. Bogor

Yadav, S.K; D.K. Singh; S. Sinha. 2014. Chemical Carbonization of Papaya Seed Originated Chrocoals for Sorpstionof $\mathrm{Pb}$ (II) From Aqueous Solution. Journal of Environmental Chemical Engineering. 